Ключевые слова: уличные насаждения, инвентаризация насаждений, видовая структура, санитарная оценка, вредители и болезни.

Dudyn R.B., Levus' T.M., Fitak M.M. The State of Outdoor Spaces in

\section{Khmelnitsky Downtown}

Species composition which is formed by 35 species and cultivars of woody plants is researched on the basis of studies of outdoor spaces in Khmelnitsky downtown conducted in 2015. They are divided into classes according to their share of participation in the plantations, and are dominated by species that are rare (less than $0.5 \%$ ). The relationship between the length of the street and the number of plants growing in it isn't found. Sanitary spaces are evaluated, and the most common lesions and diseases of woody plants, including mistletoe, horse-chestnut leaf miner, stem rot and mechanical damage are determined.

Keywords: outdoor spaces, inventory of vegetation, species structure, health assessment, pests and disease.

\section{УДК 634.017}

\section{ОСОБЛИВОСТІ ПЕРЕБІГУ ПЕРІОДУ СПОКОЮ MORUS ALBA L. ТА ЇЇ ДЕКОРАТИВНИХ ФОРМ В УМОВАХ ПРАВОБЕРЕЖНОГО ЛІСОСТЕПУ УКРАЇНИ}

\section{B.A. Віменко ${ }^{1}$}

Досліджено особливості перебігу періоду спокою Morus alba L. та ï̈ декоративних форм: M. a. 'Pendula', M. a. 'Globosa', M. a. 'Pyramidalis', M. a. 'Contorta', M. a. 'Tatarica' та M. a. 'Macrophylla' в умовах Правобережного Лісостепу України (Уманського національного університету садівництва та Національного дендрологічного парку "Софіїв" НАН України). Встановлено, шо рослини які зростють на шій території, маюов коротй роткий перід вимушеного спокою, але під дією зовнішніх чинників (низької температури повітря, зниження освітлення) він переходить у вимушений тривалий. Визначено, що найкоротший період вимушеного періоду спокою притаманний М. а., а найдовший - M. a. 'Macrophylla' та M. a. 'Pyramidalis'.

Ключові слова: вимушений період спокою, декоративні форми, органічний або фізіологічний Morus alba L., M. a. 'Pendula', M. a. 'Globosa', M. a. 'Pyramidalis', M. a. 'Contorta', M. a. 'Tatarica', M. a. 'Macrophylla'

Вступ. У ході еволюційного розвитку багаторічні рослини (зокрема плодові) виробили пристосування для переживання несприятливих умов середовища в різні періоди року. Таким пристосуванням є період спокою рослин. Тривалість періоду спокою інтродукованих рослин з різних родин і родів напряму залежить від їхнього природного ареалу. Деревні рослини із субтропічної зони, інтродуковані в умовах помірної кліматичної зони, переносять несприятливі погодні умови (зиму), вступаючи у вимушений період спокою.

Під час переходу у стан спокою утворюються тканини, які ізолюють рослину чи ії орган від зовнішнього середовища, а також відбуваються фізіологічні і біохімічні зміни у клітинах, що призводять до відокремлення їх протоплазми, збагачення ліпідами, вуглеводами, зневоднення цього рослинного організму, зміни співвідношення між інгібіторами і стимуляторами росту [1]. До вступу плодових рослин у період спокою упродовж року вони проходять період росту (набрякання і розпускання бруньок, цвітіння і вегетативний ріст). Ці процеси відбуваються у весняний період.

До середини літа із підвищенням температури повітря і грунту погіршується забезпечення рослин водою, а також під впливом вироблених у рослин біохімічних особливостей інтенсивний ріст у більшості з них припиняється. В умовах посушливого клімату окремі види рослин вступають у стан спокою в літній період, активізуючи ростові процеси за покращення водного режиму [2, 3]. До осені, 3 пониженням температури і зміною сонячного освітлення, життєдіяльність рослин сповільнюється. До цього періоду припиняється ріст пагонів і настає листопад - період скидання листя листопадними рослинами.

3 настанням зимового періоду, коли температура знижується нижче $0{ }^{\circ} \mathrm{C}$, знижується ступінь освітлення, ускладнюється поглинання та рух мерзлої води в рослинах, інтенсивність процесів асиміляції й дисиміляції і процеси росту в різних частинах рослини зменшуються до мінімуму [3].

Період спокою рослин поділяють на органічний або фізіологічний і вимушений. Перший зумовлений певним поєднанням внутрішніх факторів і їх взаємодією з середовищем, а другий характеризується різкими відхиленнями зовнішніх факторів від звичайних умов життя. Глибокий спокій пов'язують із загартуванням рослин та їх морозостійкістю.

Про біологічну сутність періоду спокою плодових культур у літературі немає єдиної думки. А. Шимпер і В. Пфефер період спокою розцінюють як внутрішню притаманну рослині властивість, що не залежить від зовнішніх умов [4]. Клебс Г., Лакон Г. трактують період спокою як результат гальмівної дії несприятливих умов на ріст рослин. Вони вважають, що рослини вступають у стан спокою під впливом зниження температури і послаблення інтенсивності освітлення в осінньо-зимовий період та погіршення несприятливих умов на їх ріст [1].

Сергеєв Л.І. (1953) стверджує, що за відповідних умов внутрішнього середовища формування частин квітки у бруньці самої бруньки може відбуватися менш ніж за 2 місяці, при цьому зовсім не обов'язково, щоб бруньки пройшли зимовий період зимового спокою [5]. Мичурін І.В. наголошував, що період спокою залежить від спадковості та зовнішніх умов і його можна скоротити чи зовсім виключити. Як приклад, сіянець груші під впливом прищепи лимона в умовах теплиці 3 роки зберігав одні і ті ж листки [6].

Мета роботи - дослідити особливості періоду спокою Morus alba L. та iï декоративних форм в умовах помірної кліматичної зони України.

Методи дослідження. Визначення періоду спокою здійснено за методикою С.Я. Нестерова [2].

Об'єкт дослідження - Morus alba L. та її декоративні форми: M. a. 'Pendula', M. a. 'Globosa', M. a. 'Pyramidalis', M. a. 'Contorta', M. a. 'Tatarica' та M. $a$. 'Macrophylla'

Результати дослідження. Різні рослини по-різному реагують на зміну температурного режиму зовнішнього середовища впродовж вегетаційного сезону і відповідно до цього мають різну тривалість періоду спокою. За цими розбіжностями їх можна поділити на три основні групи:

- рослини тропічної зони (які практично не мають ні глибокого, ні вимушеного періоду спокою). У таких рослин майже одночасно опадає старе листя та росте нове;

$\begin{array}{ll}\text { 1. Лісове та садово-паркове господарство } & 47\end{array}$ 
• рослини субтропічної зони (які мають короткий період вимушеного спокою, а в умовах помірних широт цей період переростає у тривалий);

- рослини помірної кліматичної зони (які переносять несприятливий осінньо-зимовий період, вступаючи у період глибокого спокою)

Опрацювавши літературні дані з цього питання, дійшли висновку, що період спокою - це відповідний стан рослини, в якому вона може пережити несприятливі умови зовнішнього середовища в різні періоди (етапи) свого розвитку. Дослідження проводили впродовж трьох років (2013-2015 рр.). Через кожні десять днів (починаючи з третьої декади листопада) нарізали однорічні пагони обраних рослин і ставили їх у воду в теплому приміщенні, де температура підтримувалась в межах $18-20^{\circ} \mathrm{C}$. Надалі, за потреби, замінювали воду і спостерігали за початком набухання бруньок - якщо впродовж 30 діб не було процесу набухання, то рослини ще перебували у періоді глибокого спокою (рис.)

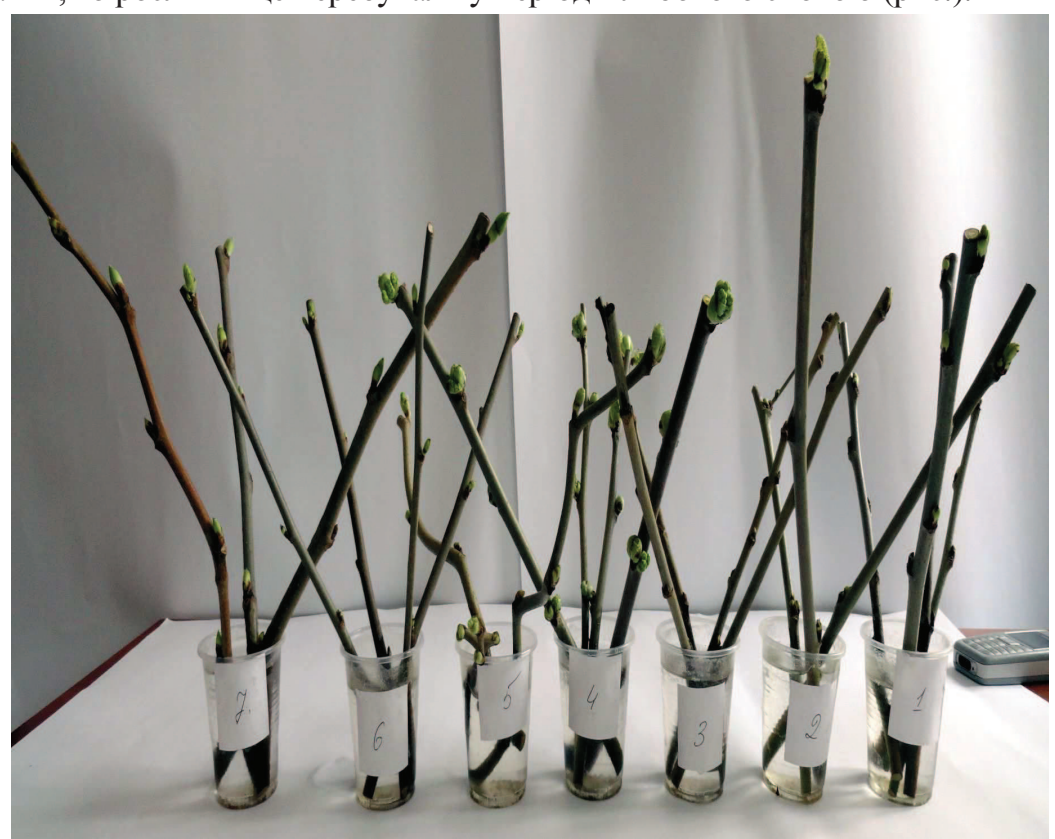

Pис. Здерев'янілі живці декоративних форм Morus alba L. на пророщуванні

3 рис. видно, що фаза набухання бруньок у M. a. та ії декоративних форм відбувається з невеликими проміжками у часі. У табл. 1 наведено дані щодо перебігу періоду спокою $M$. .

3 даних табл. 1 видно, що в разі встановлення живців $M$. .. на пророщування 30 листопада, початок набухання бруньок спостерігався 26 грудня, а тривалість періоду спокою становила 26 діб. У разі встановлення живців на пророщування 10 грудня відбувалось поступове зменшення цього періоду до 24 діб. Під час наступного закладання живців (20-30 грудня та 10 січня) зафіксовано різке скорочення настання фази початку набухання бруньок - 15 діб. Упродовж наступних дослідів (20-30 січня та 10-20 лютого) фаза набухання бруньок у $M$.

Збірник науково-технічних праць

a. наставала через 10-11 діб після їх початку. Досліди, які проводили 5, 15 та 25 березня, дозволили відзначити початок набухання бруньок через 8 діб. 3 початком квітня (5.04.) цю фазу спостерігали через 5 діб, а в разі закладання досліду 15.04 набухання бруньок розпочалось вже через 3 доби (18.04), що збіглося з початком набухання бруньок на рослинах, котрі зростають у відкритому грунті. У табл. 2 наведено дані з вивчення періоду спокою у M. a. 'Pendula'.

Табл. 1. Перебіг періоду спокою М. а. (середнє за три роки)

\begin{tabular}{|c|c|c|c|}
\hline \multirow{2}{*}{$\begin{array}{l}\text { № } \\
\text { 3/ח }\end{array}$} & \multirow{2}{*}{ Назва рослини } & \multicolumn{2}{|c|}{ Дата проведення досліджень } \\
\hline & & початок & кінець \\
\hline 1 & \multirow{14}{*}{ Morus alba L. } & 30.11 . & $26.12 . \pm 2-3$ \\
\hline 2 & & 10.12 . & $03.01 . \pm 2-3$ \\
\hline 3 & & 20.12 . & $5.01 . \pm 2-4$ \\
\hline 4 & & 30.12 . & $15.01 . \pm 2-3$ \\
\hline 5 & & 10.01 . & $25.01 . \pm 2-3$ \\
\hline 6 & & 20.01 & $31.01 . \pm 1-2$ \\
\hline 7 & & 30.01 . & $11.02 . \pm 1-2$ \\
\hline 8 & & 10.02 . & $21.02 . \pm 1$ \\
\hline 9 & & 20.02 . & $02.03 . \pm 1$ \\
\hline 10 & & 05.03 . & $13.03 . \pm 1$ \\
\hline 11 & & 15.03. & $23.03 . \pm 1$ \\
\hline 12 & & 25.03 . & $02.04 . \pm 1$ \\
\hline 13 & & 05.04 . & $10.04 . \pm 1$ \\
\hline 14 & & 15.04. & $18.04 . \pm 1$ \\
\hline
\end{tabular}

Табл. 2. Перебіг періоду спокою М. а. 'Реndula' (середнє за три роки)

\begin{tabular}{|c|c|c|c|}
\hline \multirow{2}{*}{$\begin{array}{l}\text { № } \\
\text { 3/П }\end{array}$} & \multirow{2}{*}{ Назва рослини } & \multicolumn{2}{|c|}{ Дата проведення досліджень } \\
\hline & & початок & кінець \\
\hline 1 & \multirow{14}{*}{ M. a. 'Pendula' } & 30.11 . & $27.12 . \pm 3-4$ \\
\hline 2 & & 10.12 . & $05.01 . \pm 3-4$ \\
\hline 3 & & 20.12 . & $10.01 . \pm 3-4$ \\
\hline 4 & & 30.12 . & $20.01 . \pm 3-4$ \\
\hline 5 & & 10.01 . & $28.01 . \pm 3-4$ \\
\hline 6 & & 20.01. & $04.02 . \pm 1-2$ \\
\hline 7 & & 30.01 . & $12.02 . \pm 1-2$ \\
\hline 8 & & 10.02 . & $23.02 . \pm 1$ \\
\hline 9 & & 20.02 . & $04.03 . \pm 1$ \\
\hline 10 & & 05.03. & $14.03 . \pm 1$ \\
\hline 11 & & 15.03 . & $24.03 . \pm 1$ \\
\hline 12 & & 25.03 . & $03.04 . \pm 1$ \\
\hline 13 & & 05.04 . & $11.04 . \pm 1$ \\
\hline 14 & & 15.04. & $19.04 . \pm 1$ \\
\hline
\end{tabular}

Характеризуючи дані табл. 2, варто зазначити деякі відмінності у перебігу періоду спокою в однієї із форм $M$. a. - M. a. 'Pendula'. Початок набухання бруньок у разі занурення живців у воду 30 листопада спостерігався 27 грудня, а тривалість періоду спокою становила 27 діб. У разі закладання досліду 10 грудня початок набухання бруньок настав через 26 діб. Закладання живців (2030 грудня) також зафіксували різке скорочення настання фази початку набухання бруньок до 21 доби. Далі настання фази набухання бруньок у $M$. . $a$. 'Pendula'

1. Лісове та садово-паркове господарство 
було таким: у разі закладання досліду 10 січня - набухання розпочалось через 18 діб; 20 січня - через 15 діб; 10 лютого - 13 діб; 20 лютого - через 12 діб; 5 та 15 березня - 9 діб; 25 березня - через 8 діб, 5 квітня - 6 діб і 15 квітня - відповідно через 4 доби. У табл. 3 наведено дані щодо перебігу періоду спокою у $M$ a. 'Globosa'.

Табл. З. Перебіг періоду спокою М. а. 'Globosa' (середнє за три роки)

\begin{tabular}{|c|c|c|c|}
\hline \multirow{2}{*}{$\begin{array}{c}\text { № } \\
3 / \Pi \\
\end{array}$} & \multirow{2}{*}{ Назва рослини } & \multicolumn{2}{|c|}{ Дата проведення досліджень } \\
\hline & & початок & кінець \\
\hline 1 & \multirow{14}{*}{ M. a. 'Globosa' } & 30.11 . & $27.12 . \pm 3-4$ \\
\hline 2 & & 10.12 & $05.01 . \pm 3-4$ \\
\hline 3 & & 20.12 . & $11.01 . \pm 3-4$ \\
\hline 4 & & 30.12 . & $20.01 . \pm 3-4$ \\
\hline 5 & & 10.01 . & $28.01 . \pm 3-4$ \\
\hline 6 & & 20.01 . & $03.02 . \pm 1-2$ \\
\hline 7 & & 30.01 . & $12.02 . \pm 1-2$ \\
\hline 8 & & 10.02 & $23.02 . \pm 1$ \\
\hline 9 & & 20.02 . & $03.03 . \pm 1$ \\
\hline 10 & & 05.03 . & $14.03 . \pm 1$ \\
\hline 11 & & 15.03 . & $24.03 . \pm 1$ \\
\hline 12 & & 25.03 . & $03.04 . \pm 1$ \\
\hline 13 & & 05.04 . & $10.04 . \pm 1$ \\
\hline 14 & & 15.04 & $18.04 . \pm 1$ \\
\hline
\end{tabular}

Дані табл. 3 свідчать, що в разі встановлення живців M. а. 'Globosa' на пророщування 30 листопада, набухання бруньок розпочалося 27 грудня, а тривалість періоду спокою становила 27 діб. Під час закладання живців на пророщування 10 грудня бруньки у цієї декоративної форми почали набухати через 26 діб. Подальші дослідження дали такі результати: занурення живців у воду 20 грудня - бруньки почали набухати через 22 доби; 30 грудня - 21 добу; 10 січня - 18 діб; 20 січня - відповідно через 15 діб; 30 січня та 10 і 20 лютого через 13 діб; 5, 15 та 25 березня - 9 діб; 5 квітня - 5 діб, а 15 квітня - через 3 доби. Відповідні дані для M. а. 'Pyramidalis' наведено у табл. 4.

Табл. 4. Перебіг періоду спокою М. а. 'Pуramidalis' (середнє за три роки)

\begin{tabular}{|c|c|c|c|}
\hline \multirow{2}{*}{$\begin{array}{c}\text { № } \\
\text { 3/П }\end{array}$} & \multirow{2}{*}{ Назва рослини } & \multicolumn{2}{|c|}{ Дата проведення досліджень } \\
\hline & & початок & кінець \\
\hline 1 & \multirow{14}{*}{ M. a. 'Pyramidalis' } & 30.11 . & $29.12 . \pm 3-4$ \\
\hline 2 & & 10.12 . & $08.01 . \pm 3-4$ \\
\hline 3 & & 20.12 . & $13.01 . \pm 3-4$ \\
\hline 4 & & 30.12 . & $22.01 . \pm 3-4$ \\
\hline 5 & & 10.01 . & $30.01 . \pm 3-4$ \\
\hline 6 & & 20.01 . & $05.02 . \pm 1-2$ \\
\hline 7 & & 30.01 . & $13.02 . \pm 1-2$ \\
\hline 8 & & 10.02 . & $24.02 . \pm 1$ \\
\hline 9 & & 20.02 . & $04.03 . \pm 1$ \\
\hline 10 & & 05.03 . & $15.03 . \pm 1$ \\
\hline 11 & & 15.03. & $24.03 . \pm 1$ \\
\hline 12 & & 25.03 . & $04.04 . \pm 1$ \\
\hline 13 & & 05.04. & $11.04 . \pm 1$ \\
\hline 14 & & 15.04 . & $19.04 . \pm 1$ \\
\hline
\end{tabular}

50

Збірник науково-технічних пращь
Даючи характеристику даних табл. 4, з'ясовано, що в разі закладання щойно нарізаних живців $M$. . . 'Pyramidalis' 30 листопада тривалість періоду спокою становить 29 діб, 10 грудня - початок набухання бруньок припадає на 8 січня (тривалість періоду спокою становить 28 діб). Різке зменшення тривалості початку фази набухання бруньок цієї форми (22-23 доби) спостережено, коли живці помістили у воду 20 та 30 грудня. Наступні показники наших досліджень були такими: 10 січня - набухання бруньок розпочалося через 20 діб; 20 січня 17 діб; 30 січня та 10 лютого - через 14 діб; 20 лютого - 12 діб; 5, 15 та 25 березня - відповідно через 10 та 9 діб; 5 квітня - через 6 діб, а 15 квітня - 4 доби. Дані щодо перебігу періоду спокою у $M$. . $a$. 'Contorta' наведено у табл. 5.

Табл. 5. Перебіг періоду спокою М. а. 'Contorta' (середнє за три роки)

\begin{tabular}{|c|c|c|c|}
\hline \multirow{2}{*}{$\begin{array}{l}\text { № } \\
\text { 3/П }\end{array}$} & \multirow{2}{*}{ Назва рослини } & \multicolumn{2}{|c|}{ Дата проведення досліджень } \\
\hline & & початок & кінець \\
\hline 1 & \multirow{14}{*}{ M. a. 'Contorta' } & 30.11. & $26.12 . \pm 3-4$ \\
\hline 2 & & 10.12 & $06.01 . \pm 3-4$ \\
\hline 3 & & 20.12 & $08.01 . \pm 3-4$ \\
\hline 4 & & 30.12. & $17.01 . \pm 3-4$ \\
\hline 5 & & 10.01 & $27.01 . \pm 3-4$ \\
\hline 6 & & 20.01 & $01.02 . \pm 1-2$ \\
\hline 7 & & 30.01 & $11.02 . \pm 1-2$ \\
\hline 8 & & 10.02 & $22.02 . \pm 1$ \\
\hline 9 & & 20.02 & $02.03 . \pm 1$ \\
\hline 10 & & 05.03 . & $13.03 . \pm 1$ \\
\hline 11 & & 15.03. & $23.03 . \pm 1$ \\
\hline 12 & & 25.03. & $02.04 . \pm 1$ \\
\hline 13 & & 05.04 . & $10.04 . \pm 1$ \\
\hline 14 & & 15.04. & $18.04 . \pm 1$ \\
\hline
\end{tabular}

Аналізуючи отримані дані табл. 5, виявлено досить невелику різницю у перебігу фази набухання бруньок у $M . a$. 'Contorta' та інших декоративних форм м. а. У разі закладання живців цієї форми у воду (30 листопада та 10 грудня) набухання бруньок розпочалося через 26 діб. Досліди, закладені 20 грудня, вказують на початок набухання бруньок 8 січня (через 19 діб). Подальші досліди 3 перебігу фази набухання бруньок у $M$. . $a$. 'Contorta' дали такі результати: під час закладання досліду 30 грудня - набухання розпочалось через 18 діб; 10 січня через 17 діб; а 20 січня відбулось різке зменшення тривалості періоду набухання бруньок - 12 діб; 30 січня і 10 лютого тривалість періоду набухання бруньок також становила 12 діб; 20 лютого - через 10 діб; 5 та 15 березня - через 8 діб; 25 березня - 7 діб; 5 квітня - через 5 діб, а 15 квітня відповідно через 3 доби. У табл. 6 наведено дані щодо перебігу періоду спокою M. a. 'Tatarica'

3 даних табл. 6 видно, що в разі встановлення живців $M$. a. 'Tatarica' на пророщування 30 листопада, набухання бруньок розпочалося 27 грудня, а тривалість періоду спокою становила 28 діб. Коли живці помістили на пророщування 10 грудня, розпочалось поступове зменшення цього періоду до 27 діб. За наступного закладання живців 20 грудня зафіксовано різке скорочення настання фази початку набухання бруньок - 20 діб, а 30 грудня - відповідно 18 діб. Упродовж наступних дослідів (20, 30 січня та 10 лютого) фаза набухання 
бруньок у $M$. a. L. розпочалась через 12-13 діб після їх початку. Під час проведення аналогічного досліду 20 лютого, виявлено початок набухання бруньок через 10 діб. 3 початком березня (5.03.,15.03. та 25.03.) цю фазу спостерігали через 8-9 діб, а в разі закладання досліду 5 квітня набухання бруньок зафіксовано вже через 5 діб; 15 квітня - відповідне набухання бруньок спостережено (18.04), що збіглося з початком набухання бруньок на рослинах, котрі зростають у відкритому грунті. Дані з вивчення періоду спокою у M. a. 'Macrophylla' наведено у табл. 7.

\begin{tabular}{|c|c|c|c|}
\hline \multirow{2}{*}{$\begin{array}{l}\text { № } \\
\text { 3/ח }\end{array}$} & \multirow{2}{*}{ Назва рослини } & \multicolumn{2}{|c|}{ "Дата проведення досліджень } \\
\hline & & початок & кінець \\
\hline 1 & \multirow{14}{*}{ M. a. 'Tatarica' } & 30.11. & $27.12 . \pm 3-4$ \\
\hline 2 & & 10.12 & $06.01 . \pm 3-4$ \\
\hline 3 & & 20.12 & $09.01 . \pm 3-4$ \\
\hline 4 & & 30.12 & $17.01 . \pm 3-4$ \\
\hline 5 & & 10.01. & $26.01 . \pm 3-4$ \\
\hline 6 & & 20.01 & $01.02 . \pm 1-2$ \\
\hline 7 & & 30.01 & $11.02 . \pm 1-2$ \\
\hline 8 & & 10.02 & $23.02 . \pm 1$ \\
\hline 9 & & 20.02 & $02.03 . \pm 1$ \\
\hline 10 & & 05.03 . & $13.03 . \pm 1$ \\
\hline 11 & & 15.03. & $23.03 . \pm 1$ \\
\hline 12 & & 25.03. & $03.04 . \pm 1$ \\
\hline 13 & & 05.04. & $10.04 . \pm 1$ \\
\hline 14 & & 15.04 & $18.04 . \pm 1$ \\
\hline
\end{tabular}

Табл. 7. Перебіг періоду спокою М. а. 'Macrophylla' (середнє за три роки)

\begin{tabular}{|c|c|c|c|}
\hline \multirow{2}{*}{$\begin{array}{l}\text { № } \\
\text { 3/ח }\end{array}$} & \multirow{2}{*}{ Назва рослини } & \multicolumn{2}{|c|}{ "Дата проведення досліджень } \\
\hline & & початок & кінець \\
\hline 1 & \multirow{14}{*}{ M. a. 'Macrophylla' } & 30.11 . & $28.12 . \pm 3-4$ \\
\hline 2 & & 10.12 . & $07.01 . \pm 3-4$ \\
\hline 3 & & 20.12 . & $11.01 . \pm 3-4$ \\
\hline 4 & & 30.12 . & $21.01 . \pm 3-4$ \\
\hline 5 & & 10.01 . & $31.01 . \pm 3-4$ \\
\hline 6 & & 20.01 . & $05.02 . \pm 1-2$ \\
\hline 7 & & 30.01 . & $13.02 . \pm 1-2$ \\
\hline 8 & & 10.02 . & $24.02 . \pm 1$ \\
\hline 9 & & 20.02 . & $04.03 . \pm 1$ \\
\hline 10 & & 05.03 . & $14.03 . \pm 1$ \\
\hline 11 & & 15.03. & $24.03 . \pm 1$ \\
\hline 12 & & 25.03 . & $03.04 . \pm 1$ \\
\hline 13 & & 05.04 & $10.04 . \pm 1$ \\
\hline 14 & & 15.04. & $19.04 . \pm 1$ \\
\hline
\end{tabular}

3 даних табл. 7 видно, що набухання бруньок в разі закладання живців M. a. 'Macrophylla' у воду 30 листопада розпочалося 28 грудня, а тривалість періоду спокою становила 28 діб. Під час закладання досліду 10 грудня початок набухання бруньок розпочалось через 27 діб. Закладання живців у воду 20 30 грудня та 10 січня також зафіксували різке скорочення настання фази почат- ку набухання бруньок до 21 доби. Далі початок перебігу фази набухання бруньок у M. a. 'Macrophylla' був таким: у разі закладання досліду 20 січня - набухання розпочалось через 16 діб; 30 січня та 10 лютого - через 14 діб; 20 лютого - через 12 діб; 5, 15 та 25 березня - 8-9 діб, 5 квітня - 5 діб, а 15 квітня відповідно через 4 доби.

\section{Висновки:}

1. Проведено дослідження з визначення тривалості періоду спокою $M$. $a$. та її декоративних форм: M. a. "Pendula", M. a. "Globosa", M. a. "Pyramidalis", M. a. "Contorta", M. a. "Tatarica" та M. a. "Macrophylla".

2. Встановлено, що всі досліджувані рослини в умовах Правобережного Лісостепу України мають короткий період вимушеного спокою, але під дією зовнішніх чинників (низької температури повітря, зниження освітлення) він переходить у вимушений тривалий.

3. Визначено, що найкоротший період вимушеного періоду спокою притаманний M. a., а найдовший - M. a. 'Macrophylla' та M. $a$. 'Pyramidalis'

\section{Література}

1. Кефели В.И. Природные ингибиторы и их участие в росте растений : автореф. дисс. на искание учен. степени канд. с.-х. наук / В.И. Кефели. - М., 1965. - 23 с.

2. Нестеров С.Я. Период покоя плодовых культур / Я.С. Нестеров. - М. : Изд-во с.-х. литры, журналов и плакатов, $1962 .-152 \mathrm{c}$

3. Нестеров С Я Период - 1поки и зимостойкость птодовых культур / С Я. Нестеров // Доклады Ан ССР. - М., 1957. - Т. 117, № 3. - С. 57-64.

4. Шимпер А. "География растений на физиологической основе" / А. Шимпер. - Германия, 1898. [Электронный ресурс. - Доступный с http://ashipunov.info/shipunov/school/books/rozenberg 2000 ekologija.pdf

5. Сергеев Л.И. О глубоком (органическом) покое древесных растений / Л.И. Сергеев,

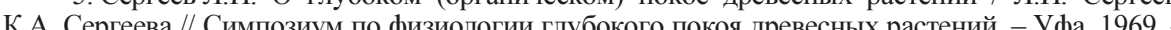
C. $5-8$.

6. Мичурин И.В. Сильные морозы прошедшей зимой и вред нанесенный ими в наших садах / В.И. Мичурин // Сад и огород. - М., 1929. - № 9. - С. 4-14.

Надіслано до редакції 22.01.2016 р..

Витенко В.A. Особенности прохождения периода покоя Morus al-

\section{$b a$ L. в условиях Правобережной Лесостепи Украины}

Исследованы особенности прохождения периода покоя Morus alba L. и ее декоративных форм M. $a$. 'Pendula', M. $a$. 'Globosa', M. a. 'Pyramidalis', M. $a$. 'Contorta', M. $a$. 'Tatarica' та M. a. 'Macrophylla' в условиях Правобережной Лесостепи Украины (Уманского национального университета садоводства и Национального дендрологического парка "Софиевка" НАН Украины. Установлено, что растения, которые растут на этой территории, имеют краткий период принудительного периода покоя, однако под действием наружных признаков (низкой температуры, снижения освещенности) он переходит в длительный принудительный. Определено, что наиболее краткий период принудительного покоя характерный Morus alba L., а наиболее длительный - M. a. 'Macrophylla' и M. a. 'Pyramidalis'

Ключевые слова: принудительный период покоя, декоративные формы, Morus al$b a$ L., M. a. 'Pendula', M. a. 'Globosa', M. a. 'Pyramidalis', M. a. 'Contorta', M. a. 'Tatarica', M. a. 'Macrophylla'.

Vitenko V.A. Some Peculiarities of the Rest Period of Morus alba L. and its Decorative Forms in Terms of Right-Bank Forest-Steppe of Ukraine

Some peculiarities of the rest period of Morus alba L. and its decorative forms such as M. a. 'Pendula', M. a. 'Globosa', M. $a$. 'Pyramidalis', M. $a$. 'Contorta', M. $a$. 'Tatarica' and $M$.

1. Лісове та садово-паркове господарство 
a. 'Macrophylla' are studied in terms of Right-Bank Forest-Steppe of Ukraine (Uman National University of Horticulture and National Dendrological Park "Sofiyivka" NAS of Ukraine). It is found that plants that grow in this area have a short period of induced dormancy but under the influence of external factors (low temperature, reducing lighting) it goes into the prolonged induced dormancy. It is determined that the shortest period of induced dormancy is inheged induced dormancy. It is determined that the shortest period of induced dotm

Keywords: period of induced dormancy, decorative forms, organic or physiological Mo-
Ko rus alba L., M. a. 'Pendula', M. a. 'Globosa', M. a. 'Pyramidalis', M. a. 'Contorta', M. a. 'Tatarica', M. a. 'Macrophylla'.

\section{УДК 599.735.31/636.084.55}

\section{ЕКОЛОГІЯ ЖИВЛЕННЯ ОЛЕНІВ}

\section{І.В. Вудмаска ${ }^{1}$, А.П. Петрук ${ }^{2}$, Б.І. Колісник}

Розглянуто особливості анатомічної будови і функціонування травної системи оленів з урахуванням видових відмінностей та типу живлення. Подано перелік рослин, які становлять основу кормової бази оленів. Висвітлено сезонні та вікові аспекти живлення оленів, динаміку змін кормових потреб залежно від фізіологічного стану тварин. На підставі аналізу світової літератури, викладено основні підходи до організації підгодівлі оленів за їх утримання у природних умовах та вольєрах, а також годівлі оленів на фермах. Для запобігання зменшенню чисельності популяції потрібний контроль природних кормових ресурсів та розроблення на основі їх аналізу кормових добавок, які дадуть змогу поповнювати дефіцит поживних і біологічно активних компонентів раціону.

Ключові слова: олень, травлення, живлення, корм, сезонність.

Особливістю травлення жуйних є попередня ферментація більшої частини поживних речовин корму мікроорганізмами рубця, після чого продукти ферментації та мікроорганізми (бактерії, протисти, гриби) засвоює тварина [3, 29, 30]. Це зумовлено специфічною будовою травної системи, зокрема наявністю складного шлунка, який містить чотири відділи: рубець, книжку, сітку та сичуг, перші три $з$ яких передшлунки і тільки останній - справжній шлунок. Саме у передшлунках відбувається розщеплення вуглеводів корму до летких жирних кислот, протеїну до амінокислот та аміаку, гідрогенізація ненасичених жирних кислот ліпідів. Леткі жирні кислоти всмоктуються і використовуються твариною в енергетичних і пластичних процесах, з аміаку синтезуються амінокислоти білків бактерій рубця. Завдяки такому типу травлення жуйні тварини здатні засвоювати неперетравну для тварин з однокамерним шлунком целюлозу та геміцелюлозу, а засвоєння у сичузі та кишечнику рубцевих мікроорганізмів забезпечує жуйну тварину повноцінним протеїном та вітамінами групи В та К.

Інші травоїдні тварини частково ферментують клітковину в сліпій кишці, з якої всмоктуються леткі жирні кислоти, але не засвоюється мікробний протеїн. Наявність складного шлунка дає жуйним тваринам можливість ефективно засвоювати грубі корми, проте має певний недолік - склад раціону повинен бути відносно стабільним. У разі зміни корму в екосистемі передшлунків повинен змінитись видовий і кількісний склад мікроорганізмів, що триває в середньому

проф. І.В. Вудмаска, д-р с.-г. наук - Інститут біології тварин НАAН; доц. А.П. Петрук, канд. біол. наук - Львівський НУ ветеринарної медицини та біотехнологій ім. С.З. Гжицького; помічник ректора Б.І. Колісник, канд. економ. наук - НЛТУ України, м. Львів два тижні [30]. Тому нові корми до складу раціону вводять поступово і згодовують їх регулярно, що потрібно враховувати під час організації підгодівлі диких жуйних. Крім цього, травна система жуйних тварин, незважаючи на однакові у цілому анатомічну будову та фізіолого-біохімічну функцію, має певні особливості у різних видів, що зумовлює відмінності їх живлення.

Згідно з найпоширенішою на цей час класифікацією $[5,12,13,18]$, за кормовими пріоритетами жуйних поділяють на споживачів грубих кормів (grazers), споживачів концентрованих кормів (browsers) та проміжний тип (табл. 1). Треба враховувати, що у цьому разі термін "концентровані корми" означає не звичні для нашої термінології насіння злакових та бобових рослин, а листя, пагони та кору дерев і кущів, які порівняно з травою і сіном, містять більше протеїну та менше клітковини.

До споживачів грубих кормів належать тварини, раціон яких більше ніж на $75 \%$ складається із грубих кормів. Раціон споживачів концентрованих кормів містить понад до 25 \% грубих кормів. Інших жуйних відносять до проміжного типу. Анатомічно травна система споживачів грубих кормів відрізняється від травної системи споживачів концентрованих кормів коротшим язиком, меншим розміром слинних залоз, більшим об'ємом рубця, меншим отвором між книжкою і сіткою, меншою кількістю сосочків на стінці рубця, меншим об'ємом сичуга, довшим кишечником [27]. Загальна довжина кишечника споживачів грубих кормів у 25-30 разів більша за довжину тіла, тоді як у споживачів концентрованих кормів розмір кишечника більший за довжину тіла тільки у 12-15 разів. Разом з тим, у споживачів концентрованих кормів товстий кишечник становить 27-35 \% від загальної довжини кишечника, а у споживачів грубих кормів частка товстого кишечника - тільки 18-20 \% [13]. У різних за типом живлення жуйних відрізняється склад слини. Слина споживачів концентрованих кормів містить компоненти, які нейтралізують антипоживні речовини - танін-зв'язувальні протеїни [4]. Крім цього, у них удвічі більша печінка (у перерахунку на вагу тіла), що дає змогу ефективніше нейтралізувати шкідливі компоненти корму [13, 29].

Табл. 1. Класифікація жуйних тварин за типом живлення [13]

\begin{tabular}{|c|c|c|}
\hline $\begin{array}{c}\text { Споживач концентрованих } \\
\text { кормів (browsers) }\end{array}$ & Проміжний тип & \begin{tabular}{|c|} 
Споживач грубих \\
та об'ємистих \\
кормів (grazers) \\
\end{tabular} \\
\hline $\begin{array}{c}\text { Лось звичайний (Alces alces); } \\
\text { Сарна європейська } \\
\text { (Capreolus capreolus); } \\
\text { Білохвостий олень } \\
\text { (Odocoileus virginianus); } \\
\text { Чорнохвостий олень } \\
\text { (Odocoileus hemionus); } \\
\text { Кабарга (Moschus); } \\
\text { Мунтжак (Muntiacus) }\end{array}$ & $\begin{array}{c}\text { Коза свійська (Capra hircus); } \\
\text { Благородний олень } \\
\text { (Cervus elaphus); } \\
\text { Плямистий олень (Cervus nippon); } \\
\text { Північний олень } \\
\text { (Rangifer tarandus); } \\
\text { Лань європейська (Dama dama); } \\
\text { Козиця звичайна } \\
\text { (Rupicapra rupicapra) }\end{array}$ & \begin{tabular}{|l} 
Велика рогата ху- \\
доба (Bos taurus); \\
Вівця свійська \\
(Ovis aries); \\
Зубр \\
(Bison bonasus) \\
Муфлон євро- \\
пейський \\
(Ovis musimon) \\
\end{tabular} \\
\hline
\end{tabular}

Для встановлення потреби оленів у поживних речовинах й енергії потрібно враховувати мету утримання. Олені цілком можуть існувати споживаючи природні корми, оскільки до цього вони пристосовані еволюційно. Оленеві на- 